\title{
Gender Aspects of Mutual Effectiveness of Socio-Economic Strategies for Choice of Profession and Employment of Young Specialists
}

\author{
Ardak Bazarbekovich Montayev ${ }^{{ }^{*}}$ \\ Mansya Sapargalievna Sadyrova ${ }^{2}$ \\ Assel Sarsenova ${ }^{2}$ \\ Nazym Utegalievna Shedenova ${ }^{2}$ \\ ${ }^{1}$ Department of Political Science, \\ M. Auezov South Kazakhstan University, \\ Shyment, Kazakhstan \\ ${ }^{2}$ Department of Sociology and Social Work, \\ Al-Farabi Kazakh National University, \\ Almaty, Kazakhstan \\ ${ }^{*}$ Corresponding Author
}

DOI: https://doi.org/10.36941/ajis-2022-0051

\begin{abstract}
The present study aims to identify the gender characteristics of professional orientations and strategies for building a professional career by young professionals. Based on sociological data, the author examines the main ways and features of youth employment according to the chosen profession. Informal employment channels through acquaintances and social networking are more effective than formal. Young women are more likely to face barriers to employment due to a lack of practical work skills and length of service. Young men more often point to the lack of demand for their profession in the labor market and are more oriented on financial standing.
\end{abstract}

Keywords: gender, secondary career choice, young professional, job, profession

\section{Introduction}

The choice of profession is one of the weighty indicators of the formation of a specialist that meets the requirements of the future labor market, traditional career strategies for young people now lead to inefficient employment. At present, global socio-economic changes in the structure of the world economy and an orientation toward the formation of a society $5 \mathrm{D}$ to put new models and forms of career choice.

The success of a person's life largely depends on the choice of his future profession. Making the right choice is not an easy task. Young people in Western countries are equipped with the necessary knowledge to develop their taste and innate professional ability. All responsibility for the choice of profession depends on the young man and his parents. Modern trends in the labor market and the 
requirements of the future specialist society require young people to form and correctly assess their tastes and abilities, on the one hand. On the other hand, there is a growing need to take into account the needs of the labor market for training specialists in new areas of the economy. This is also dictated by the death of traditional, modernization of existing, the emergence of new professions. Just personal interest, the desire to know the chosen profession gives a person a better chance of success in professional and personal life. Since the data of mass surveys over the past decades show that the Kazakh and Russian society manifests itself as a very stereotypical and traditionally perceiving the role positions of women and men, especially in the labor market, the authors focused on gender differences in the responses to the questionnaire, simultaneously noting other significant differences

At the theoretical level, this work studies the degree of influence of professional motivation on the dynamics of attitude to the profession and employment in graduates and young professionals (Srijit, 2009). Factors influencing the choice of profession are considered in the context of the modern system of higher education and the labor market. The information obtained based on the presented list of indicators allows us to assess the state of the choice of profession and satisfaction with the profession in graduates and young professionals, as well as identify factors influencing their formation (Srijit, 2009). Implementing the provisions of monitoring the choice of profession and satisfaction with vocational education institutions in graduates and young professionals will form indicators to assess the effectiveness of the employment process and improve the quality of education (Srijit, 2009).

The professional choice of graduates is interconnected with the implementation of such social values as the possibility of creating conditions for creativity, qualified growth and promotion, receiving material remuneration, inclusion in a certain sphere of work, social recognition. Interests, attitudes, value orientations in relation to the profession are developed in individuals in the process of socialization under the influence of family, school, small group, mass communication. In the mind of a young man, a hierarchy of professions is formed by attractiveness, a scale of preferences, differentiated depending on his social origin, conditions of education, type of residence and others. In the process of professional choice, there may be a contradiction between the interests, personal plans, inclinations of the individual and the external situation in relation to him, as a result of which the personal plans of individuals can change significantly. Stability of interests, attitudes of the graduates offer a professional choice, by conviction, and not by coincidence. This is a prerequisite for high labor productivity, job satisfaction of the young specialist.

Today the profession is traditionally considered as a personified set of social characteristics, specific specialized knowledge of skills, competencies, important for the implementation of a certain kind of work, marking the identity of the individual, social community to a specific category, the Association of individuals engaged in a similar type of work. Professional choice as a social process assumes that individuals (subjects of choice) are aware of the presence in society of the professional division of labor, specific types of work - professions, specific sets of knowledge and skills - specialties required for specific activities (objects of choice), ways and means of acquiring knowledge and skills necessary for this activity and the real possibilities of their use. In this case, it is advisable to divide it into primary (objectified intermediate result it can be considered, for example, admission to a particular educational institution), and secondary - as the beginning of a specific professional activity. At the same time, this methodology is focused on the analysis of the relative independence of the subject in choosing a profession, since it is he who subjectively forms the hierarchy of the importance of factors and assumes social responsibility for his choice. The success of a person's life depends largely on the choice of his career. Making the right choice is not an easy task. It was found that the careers of many bright young people were ruined because of wrong choices. In Western countries, students develop from the very beginning of their lives according to the tastes and natural skills they have.

They are fully equipped with all the necessary and necessary knowledge to develop their taste and innate ability. 
The motivator for entering higher education is generally perceived as an in-depth study of a particular discipline, obtaining a degree, obtaining a higher qualification and thus getting a good or better job in the future (Johnes, 2006).

Movements in the world of work are influenced by the characteristics of people's behavior in choosing a profession.

Two different models of such behavior among young people:

1. First, all professions and occupations are relatively equal in socio-economic terms, while individuals focus on equal types of work, taking into account their predispositions, desires and abilities.

2. Second, there are clearly "good" and clearly "bad" types of work in the socio-economic sense, and all, of course, are guided by "good".

In the study of the problems of choosing a profession Western sociology has passed a number of stages. The concept of "the theory of chance" of sociologists of the USA very abstractly described a choice of a profession. The content of the concept of "fading soul" is that if initially the range of possible variations in the behavior of the individual is very wide, then as you move in the process of choosing the fluctuations are reduced, and the person finally acquires a stable position.

In foreign social psychology, a slightly different idea of the motivation of the professional choice of the individual, which can be illustrated by the concepts of D. Super, J. Holland is considered the most important to explain the behavior of a person when choosing a profession, its focus and identifies the following stages:

- professional preference;

- moment of choice;

- professional achievement.

According to D. Super (1957), the choice of profession is actually identified with the choice of the method of self-understanding, makes the addition that over time and the experience gained, the very understanding of a person can change, and as a result, a new professional choice is made. John Holland (1986) describes the choice of profession as the choice of environment, coinciding with personal orientation and personality type.

As Safina R. G. notes, the term "choice" indicates a preference for any alternative from the available options. It is easy to see that there are at least two options: a professional career, by which we mean the desire to achieve high official and professional status (note that), or abandonment of it. The latter may involve, for example, choosing a career housewife (as the most obvious alternative to a professional career) or limiting aspirations to ordinary performing positions. The moment of choosing a career may not coincide with the moment of choosing a profession, although, of course, the choice of career and choice of profession are related to each other. The results of the sociological research conducted by R. G. Safina together with the research group in the Republic of Tatarstan also revealed that there are no significant differences in career motivations between boys and girls of 18-22 years old studying in economic and management specialties. The respondents showed almost the same level of career orientation, i.e. the same level of career orientation, striving for high incomes, achieving a certain level of power and influence (Safina, 2005).

Based on the procedural interpretation of the choice of profession, it is necessary to distinguish three vectors of change: professional, personal, socio-economic. The professional vector reflects the expansion of the spectrum of professions; changes in the nature and content of professional activity in society; the complexity of the requirements for personal qualities and properties of a person. The personal vector assumes a degree of coincidence and realization of needs, inclinations of the individual with professional requirements as a guarantee of successful mastering of a profession. Socio-economic vector is focused on the constant sectorial renewal of the professional spectrum in accordance with the needs of society and the representation of this need in the amount of wages, additional benefits (Sizova, Kladova \& Khusiainov, 2016).

There are three criteria by which the activity can be considered professional. The first criterion can be attributed to a certain amount and level of qualification (competence, knowledge, skills), 
confirmed by institutionalized documents (diploma, certificate, etc.). The degree of professionalism is largely determined by the level of implementation of these characteristics. The second feature of the profession is its consumer properties of marketability, i.e. the ability to sell in the labor market and the degree of its demand from employers, its "selling" value (wages as a source of income of the owner of the profession).Third, the profession is confirmed by belonging to a particular professional Association, community and interiorization of the personality common to this community (corporate behavioral) norms and values. Therefore, this comprehensive definition and criteria can be an effective tool for analyzing the characteristics of the professional aspirations of young people. Researchers from different regions have recorded that the rating of preferences of young people is headed by the most highly paid professions in Russia today - entrepreneur, financier, programmer, lawyer and professional politician. However, in reality, young people often master such specialties as humanitarians of different directions, economists, lawyers, engineers, technicians.

This issue has become particularly relevant in Kazakhstan due to the reduction of vocational schools, the growing number of private universities and the expansion of the range of paid education in national and state universities. In addition, the level of employment of University graduates in the received specialties is reduced. According to the study, there are differences in the choice of higher education of students in the context of family origin. This differentiation contributes to the stratification of universities and the concentration of working-class students in non-prestigious educational institutions with low tuition fees. Thus, there is a risk that this situation may increase the impact of the social background on the results of the labor market (salary and professional status) (Shnarbekova, 2018).

Theoretical aspects of the problem of employment have been deeply studied by foreign researchers and scientists. Around 1955, the first employment concepts were introduced. However, it was not until the late 1990s that employment opportunities began to be explored empirically from different perspectives and at different levels (individual, organizational and industrial), as well as in a wide range of academic disciplines. At the same time dramatically increased the number of studies devoted to the prediction of the behavior during the job search and outcomes-employment. Since, job search has become so common and frequent that it is now considered an integral part of the working life of people (Kanfer, Wanberg \& Kantrowitz, 2001). Hillage and Pollard argue that employment is the ability to move independently in the labor market to realize potential through sustainable employment. When looking for a job, the most important element is the purpose of the job search (Hillage \& Pollard, 1998). For example, Boswell, Budreau and Dunford note that there is little understanding of the goals or objectives of job seekers to participate in job search. Researching job search goals is important because the behavior of job seekers is likely to depend largely on their job search goals (Boswell et al., 2004). Also, when looking for work and employment, the importance of the disciplines taught is important. Bennett N., Dunne, E. and Carre, C. (1999) a model of providing a course in higher education, which included five elements, was proposed:

1. disciplinary knowledge;

2. disciplinary discipline;

3. awareness of workplace;

4. work experience;

5. general skill.

Returning to the role of education in the socio-economic strategies of graduates, let's not forget that choosing a University as the goal of admission, young people (both in Russia and in Kazakhstan) come most often not from the needs of the labor market, but based on their own expectations, knowledge, needs, economic resources and social capital (including - accumulated ties) of parents, as well as - "institutional capital", the image of the University, faculty, the prestige of its specialties.

The hypothesis of the study

HYPOTHESIS 1. Personal motivation and factors are indicators of the effectiveness of career growth and self-realization of young professionals.

HYPOTHESIS 2. Gender preferences and stereotypes have a significant impact on young 
people's choice of future profession.

HYPOTHESIS 3. The process and quality of professional education in Higher education institutions affects the choice of real professional activity of a young specialist.

HYPOTHESIS 4 . For effective successful employment of graduates is influenced by the presence of social ties.

\section{Methods}

The article is prepared on the basis of a public opinion poll among University Graduates and young professionals. The participants consisted of bachelor's degree courses. The survey was held among graduates of the Almaty and Shymkent universities. I was carried out in June and July of 2015.

The sample consisted of 300 graduates in 6 largest universities (including Almaty: KazNU. Al-Farabi Kazakh national University, S. D. Asfendiyarov KazNMU, Kazakh state teacher training University, K. Satpayev KazNTU, Shymkent: M. O. Auezov SKSU, University of Miras) structure on floor is: female floor of $76.3 \%$ male and $23.7 \%$.

A survey was carried out among professionals with higher and secondary special education (200 respondents). The research participants were young specialists employed in different state structures and enterprises (61 \% - female, 38.5 - male).

Stage 1 of the study. The questionnaire survey was conducted in 2015 among graduates in 6 universities of Almaty and Shymkent. The target quota sample made up of 300 people. The main selection criteria - sex, UNIVERSITY, specialty. The sampling error is $+/-5 \%$. The gender structure is $76.3 \%$ female and $23.7 \%$ male.

Stage 2 of the study. The questionnaire survey was conducted in 2015 among young professionals in Almaty and Shymkent. The aim of the questionnaire was to identify the dynamics of professional orientation and patterns of labor behavior after entering the labor market. The target quota sample made up of 200 people. The main selection criteria are gender ( $53 \%$ - girls, $47 \%$ - boys), age (up to 30 years), specialty. The sampling error is $+/-5 \%$.

Stage 3 of the study. In 2015, A. B. Montaev conducted a sociological study "Employment of University graduates of Russia and Kazakhstan", by means of a questionnaire. The target sample totaled 500 graduates of all faculties of West Kazakhstan agrarian technical University named after Zhangir Khan, West Kazakhstan humanitarian University named after M. Utemisov and Saratov state University named after N. D. Chernyshevsk. The graduates were chosen at random from a list provided by the heads of universities of different faculties. Data on young professionals were collected in April-June 2015 using a questionnaire. Participants were asked to complete a survey in the framework of the study to better understand the attitude to the profession among young professionals after they entered the first jobs and how University graduates relate to the chosen profession.

Factor analysis was used to process the results. Computer processing and data analysis were carried out on the basis of computer program SPSS-19.

\section{Results}

During the author's survey it was found out that $40.4 \%$ of boys have technical education, while girls with similar education 4 times less - 9.0\% (Table 1 ). At the same time, a significant proportion of girls $32.1 \%$ indicate humanitarian education than boys (14.2\%). Having pedagogical education among women was 21.8 percent, than boys of $5.7 \%$. Thus, young men more often realize themselves in technical, military specialties, while girls - in the humanitarian, pedagogical and arts fields. 
Table 1: Vocational education Profile of young people, \% by gender

\begin{tabular}{|l|c|c|c|}
\hline \multirow{2}{*}{ Profile of vocational education } & \multicolumn{2}{|c|}{ Sex } & \multirow{2}{*}{ total } \\
\cline { 2 - 3 } & woman & man & $\mathbf{2 3 , 9} \%$ \\
\hline Technical & $9,0 \%$ & $\mathbf{4 0 , 4} \%$ & $\mathbf{2 3 , 6 \%}$ \\
\hline Humanitarian & $\mathbf{3 2 , 1} \%$ & $\mathbf{1 4 , 2} \%$ & $\mathbf{1 6 , 5} \%$ \\
\hline socio-economic & $\mathbf{1 7 , 3} \%$ & $\mathbf{1 5 , 6 \%}$ & $\mathbf{1 4 , 1} \%$ \\
\hline Pedagogical & $\mathbf{2 1 , 8} \%$ & $5,7 \%$ & $9,8 \%$ \\
\hline Medical & $\mathbf{1 0 , 9} \%$ & $8,5 \%$ & $5,4 \%$ \\
\hline Military & $\mathbf{0 , 6} \%$ & $\mathbf{1 0 , 6 \%}$ & $\mathbf{2 , 0} \%$ \\
\hline Art & $5,8 \%$ & $\mathbf{2 , 1} \%$ & $\mathbf{2 , 7} \%$ \\
\hline natural-science & $\mathbf{2 , 6} \%$ & $\mathbf{2 , 8} \%$ & $\mathbf{2} \%$ \\
\hline Total & $\mathbf{1 0 0 , 0} \%$ & $\mathbf{1 0 0 , 0} \%$ & $\mathbf{1 0 0 , 0} \%$ \\
\hline
\end{tabular}

Analysis of the results showed that the majority of boys $(59.6 \%)$ and girls $(62.6 \%)$ have higher education. There are more boys with secondary special education (24.1\%) than girls (16.8\%). Boys with a second higher education are 2 times more than girls, respectively $6.4 \%$ and $3.9 \%$ (Table 2 ). But among women with postgraduate education are more (3.9 percent) than among young men (2.1 percent). Thus, girls have a higher level of aspiration to become competent in their chosen specialty, apparently, they are more purposeful than boys who are more pragmatic in their attitude to education, less purposeful, but more try themselves in different directions.

Table 2: Gender characteristics of the level of education of young people, \% by gender

\begin{tabular}{|l|c|c|}
\hline \multirow{2}{*}{ Level of education } & \multicolumn{2}{|c|}{ Sex } \\
\cline { 2 - 3 } & \multicolumn{2}{|c|}{ Moman } \\
\hline Highest & $62,6 \%$ & $59,6 \%$ \\
\hline Postgraduate & $3,9 \%$ & $6,1 \%$ \\
\hline Second highest & $3,9 \%$ & $24,1 \%$ \\
\hline Secondary special & $16,8 \%$ & $7,8 \%$ \\
\hline Medium & $\mathbf{1 2 , 9} \%$ & $100,0 \%$ \\
\hline Total & $100,0 \%$ & \\
\hline
\end{tabular}

The survey showed that the majority of young people received secondary education in the city (Table 3). However, one in four (24\%) finished school in rural areas, and only then moved to the city. This is especially true for young men $(36 \%)$, who are more than 2 times more likely to move from village to city, probably for admission to educational institutions, in search of work or more comfortable living conditions.

Table 3: Gender differences in place of education, \% by gender

\begin{tabular}{|l|c|c|c|}
\hline \multirow{2}{*}{ Area of secondary education } & \multicolumn{2}{|c|}{ Sex } & \multirow{2}{*}{ In the sample } \\
\cline { 2 - 3 } & Woman & Man & \\
\hline In rural areas & $15 \%$ & $\mathbf{3 6 \%}$ & $\mathbf{2 4} \%$ \\
\hline In the city & $\mathbf{7 6 \%}$ & $5 \mathbf{2} \%$ & $\mathbf{6 6 \%}$ \\
\hline In regional centre & $9 \%$ & $\mathbf{1 2} \%$ & $10 \%$ \\
\hline Total & $100 \%$ & $100 \%$ & $100 \%$ \\
\hline
\end{tabular}

Table 4 will help to clarify age limits social mobility of young people. Most of the respondents are probably citizens, as they graduated from the city school. However, in the age group of 20-21-yearolds - every second - comes from rural areas. In the group of $24-25$-year-olds, one in three is such: In the group of 26-27-year-olds - every fourth. 
In the group of 28 -29-year-olds - only $14 \%$.

We can assume that the youngest Saratov citizens are the most mobile, they came to Saratov from the countryside relatively recently, but not all of them will stay in the city forever. The older the youth, the more often they return to their native land or move to another place of residence.

Table 4: Age differences in place of education, \% by age category

\begin{tabular}{|l|c|c|c|c|c|c|}
\hline \multirow{2}{*}{ Area of secondary education } & \multicolumn{3}{|c|}{ Age } & \multirow{2}{*}{ In the sample } \\
\cline { 2 - 6 } & $\mathbf{2 0 - 2 1}$ & $\mathbf{2 2 - 2 3}$ & $\mathbf{2 4 - 2 5}$ & $\mathbf{2 6 - 2 7}$ & $\mathbf{2 8 - 2 9}$ & \\
\hline In rural areas & $\mathbf{5 0} \%$ & $\mathbf{0} \%$ & $35 \%$ & $\mathbf{2 5} \%$ & $\mathbf{1 4} \%$ & $\mathbf{2 4} \%$ \\
\hline In the city & $\mathbf{2 5} \%$ & $\mathbf{1 0 0} \%$ & $\mathbf{5 9} \%$ & $\mathbf{5 8 \%}$ & $\mathbf{7 7} \%$ & $\mathbf{6 6 \%}$ \\
\hline In regional centre & $\mathbf{2 5} \%$ & $\mathbf{0} \%$ & $6 \%$ & $17 \%$ & $9 \%$ & $10 \%$ \\
\hline total & $100 \%$ & $100 \%$ & $100 \%$ & $100 \%$ & $100 \%$ & $100 \%$ \\
\hline
\end{tabular}

When youth employment was identified (Table 5), it was found that there were more unemployed girls (18 per cent) than boys (16 per cent). This already shows the existing background of dissatisfaction of young people with their own professional sphere. At the same time, the main sphere of employment of girls is education (18\%), medicine (15\%) and culture (18\%), as well as the financial sector $(12 \%)$. Young men have a slightly different rating of the employment sector: it is the service sector $(32 \%)$, construction $(16 \%)$, and law enforcement agencies $(8 \%)$.

Table 5: Gender profile of youth employment, \% by gender

\begin{tabular}{|l|c|c|c|}
\hline \multirow{2}{*}{ Employment sphere } & \multicolumn{2}{|c|}{ Sex } & \multirow{2}{*}{ In the sample } \\
\cline { 2 - 3 } & Woman & Man & \\
\hline Unemployed & $\mathbf{1 8 \%}$ & $16 \%$ & $17 \%$ \\
\hline Public administration & $\mathbf{1 2} \%$ & $\mathbf{1 2} \%$ & $\mathbf{1 2} \%$ \\
\hline Culture & $\mathbf{9 \%}$ & $4 \%$ & $7 \%$ \\
\hline Education & $\mathbf{1 8 \%}$ & $0 \%$ & $\mathbf{0} \%$ \\
\hline Enforcement authorities & $3 \%$ & $\mathbf{8 \%}$ & $5 \%$ \\
\hline Construction & $6 \%$ & $\mathbf{1 6} \%$ & $\mathbf{1 0} \%$ \\
\hline Medicine & $\mathbf{1 5} \%$ & $8 \%$ & $\mathbf{1 2} \%$ \\
\hline Financial sector & $\mathbf{1 2} \%$ & $4 \%$ & $9 \%$ \\
\hline Service sector & $6 \%$ & $\mathbf{3 2} \%$ & $17 \%$ \\
\hline Total & $\mathbf{1 0 0} \%$ & $100 \%$ & $100 \%$ \\
\hline
\end{tabular}

Thus, the traditional division of labor between men and women prevails in the professional sphere of youth employment. In addition, attention is drawn to the factthat none of the young professionals did not indicate the industry as a place of work, although we recall that $23 \%$ of young people have technical education.

This indicates either the impossibility of employment in the specialty due to the low workload of industrial enterprises with orders, or that these young people studied at the University for the sake of a diploma, but not for the sake of the specialty. In other words, the choice of University for them did not mean the choice of work in the future.

Analysis in the framework of the gender approach showed that the resulting specialty like boys $(45,4 \%)$ than girls (39.5 per cent). At the same time, a significant proportion of girls $46.8 \%$ chose the option "like", which shows interest in their specialty.

However, among graduates who are undecided in relation to their specialty, boys $(14.4 \%)$ more than girls (13.7\%). Perhaps this is due to the fact that when entering this part of the applicants were not professionally oriented. Among those who do not like the chosen specialty, $3.1 \%$ were young men. Thus, female graduates are more stable in their professional orientations than boys. Professional 
choice and its implementation in terms of practical employment are socially conditioned. It largely depends on the availability of connections and opportunities, as well as on the demand for the profession in the labor market.

Of course, qualifications, individual abilities and motivation are important factors in professional mobility and in the employment of graduates, but as the results of our study show, social networks are just as important - sometimes even more important (Finko, 2006). For both boys and girls, networking is important in the search for employment. To date, social relations have become powerful tools in the labor market this is evidenced by the results of research by foreign researchers. For example, Feld (1981) studied the structure and use of social connections to emphasize how personal relationships perform a number of functions for individuals and how they function when looking for work. They are also characterized by job search through direct communication with the employer (16\%), through the state employment service $(12 \%)$, through the job fair $(4 \%)$. Girls are more focused on parents (15\%), media (12\%), Internet (9\%). Thus, young men are more likely to use direct traditional social and institutional links, and they have more confidence in public and private employment services than girls.

Table 6: Gender differences in employment methods, \% to positive gender responses

\begin{tabular}{|l|c|c|c|}
\hline \multirow{2}{*}{ Ways of employment } & Sex & & \multirow{2}{*}{ In the sample } \\
\cline { 2 - 3 } & woman & man & \\
\hline Helped parents & $15 \%$ & $8 \%$ & $\mathbf{1 2} \%$ \\
\hline Through ties known & $\mathbf{2 4} \%$ & $44 \%$ & $\mathbf{3 3 \%}$ \\
\hline Via the Internet & $9 \%$ & $8 \%$ & $9 \%$ \\
\hline Direct communication with employers & $15 \%$ & $16 \%$ & $16 \%$ \\
\hline Through the media & $\mathbf{1 2} \%$ & $8 \%$ & $10 \%$ \\
\hline Through job fair & $3 \%$ & $4 \%$ & $3 \%$ \\
\hline Through state employment programs & $9 \%$ & $\mathbf{1 2} \%$ & $10 \%$ \\
\hline
\end{tabular}

The duration of job search among the majority of young people (52\% of respondents) ranged from 1 to 3 months. To six months looking for a job mostly every third girl (30\%) and one in four youth (24\%). Speaking about the difficulties of finding a job in the specialty (Table 7 ), 39\% of respondents noted the lack of experience, practical knowledge, work experience.

Table 7: Gender differences in employment problems, \% by gender

\begin{tabular}{|l|c|c|c|}
\hline \multirow{2}{*}{ Difficulties in finding a job in the specialty } & \multicolumn{2}{|c|}{ Sex } & \multirow{2}{*}{ By sample } \\
\cline { 2 - 3 } & woman & man & \\
\hline lack of experience, practical knowledge, work experience & $44 \%$ & $32 \%$ & $39 \%$ \\
\hline there is no need for specialists of my profile today & $15 \%$ & $32 \%$ & $22 \%$ \\
\hline work in the specialty is low-paid & $27 \%$ & $32 \%$ & $29 \%$ \\
\hline I don't like my specialty & $3 \%$ & $\mathbf{0} \%$ & $\mathbf{2} \%$ \\
\hline
\end{tabular}

Especially the lack of experience was emphasized by girls (44\%). $22 \%$ of young people complained that there is no demand for specialists of their profile today. The boys paid more attention to it (32\%). They more often than girls noted that work in the specialty is low-paid (32\% against $27 \%$ ). Only $2 \%$ of young people said that their specialty they do not like. Thus, we are dealing with the consequences of the professional choice of young people in accordance with the preferences, but without taking into account the demands of the labor market. At the same time, the problem of universities with the formation of young people's competencies of practical work and with serious deformations in the field of wages emerges here. 
Table 8: Gender differences in employer requirements when applying for a job, \% positive responses on gender

\begin{tabular}{|l|l|l|l|}
\hline \multirow{2}{*}{ Quality specialist } & Sex & \multirow{2}{*}{ In the sample } \\
\cline { 2 - 3 } & Woman & man & \\
\hline Availability of education (prestige of the University, specialty, etc.) & $\mathbf{4 8 \%}$ & $\mathbf{4 4} \%$ & $\mathbf{4 7 \%}$ \\
\hline Professional competence & $\mathbf{2 1} \%$ & $36 \%$ & $\mathbf{2 8 \%}$ \\
\hline Appearance of the applicant & $\mathbf{0} \%$ & $4 \%$ & $\mathbf{2} \%$ \\
\hline Experience & $39 \%$ & $40 \%$ & $40 \%$ \\
\hline Sociability & $3 \%$ & $4 \%$ & $3 \%$ \\
\hline Character trait & $100 \%$ & $\mathbf{1 0 0} \%$ & $\mathbf{1 0 0} \%$ \\
\hline
\end{tabular}

During the analysis of the specialty in which young people currently work, it was found that $41 \%$ of girls work in the specialty obtained in the educational institution (Table 9). Another 32.7\% of girls work close to the specialty. Among young men there are less-respectively - 33,3\% and $24,1 \%$. Thus, it can be argued that the majority of young professionals (66\%) as the primary and secondary choice of profession were successful. However, an impressive number of young people (22.6\%) do not work in their specialty. Among boys such - 29,8\%, among girls - less (16\%). Thus, girls are more likely to realize the knowledge and competences gained in the course of education and are more consistent in their life and professional strategies.

Table 9: Gender-specific job satisfaction of the youth and the specialty of the diploma, \% by gender

\begin{tabular}{|l|c|c|c|}
\hline \multirow{2}{*}{ Specialty in which You are working now } & \multicolumn{2}{|c|}{ Sex } & \multirow{2}{*}{ In the sample } \\
\cline { 2 - 3 } & woman & man & \\
\hline corresponds to obtained in educational institution & $\mathbf{4 1 , 0} \%$ & $\mathbf{3 3 , 3} \%$ & $\mathbf{3 7 , 4} \%$ \\
\hline close to that obtained in the school & $32,7 \%$ & $\mathbf{2 4 , 1} \%$ & $\mathbf{2 8 , 6 \%}$ \\
\hline does not correspond to the obtained diploma & $16,0 \%$ & $29,8 \%$ & $22,6 \%$ \\
\hline I have no specialty & $10,3 \%$ & $12,8 \%$ & $11,4 \%$ \\
\hline total & $100,0 \%$ & $100,0 \%$ & $100,0 \%$ \\
\hline
\end{tabular}

The majority of young people (59.1 per cent) have jobs that match their qualifications (Table 10). For $14.8 \%$ there is a possibility of professional growth at work, as higher qualification is required. However, every fourth young person works lower qualifications than his ability. This is especially true for young men, among whom about $4 \%$ said that their work is much lower than their qualifications and another $8.3 \%$ stated their complete discrepancy. In other words, one in five young people cannot realize their potential professional and qualification opportunities in work.

Table 10: Gender-specific characteristics of the work of young people and their qualifications, \% by sex

\begin{tabular}{|c|c|c|c|}
\hline \multirow{2}{*}{ The degree of compliance with the qualification requirements of the work } & \multicolumn{2}{|c|}{ Sex } & \multirow{2}{*}{$\begin{array}{l}\text { In the } \\
\text { sample }\end{array}$} \\
\hline & woman & man & \\
\hline the job meets my qualifications & $60,7 \%$ & $57,4 \%$ & $59,1 \%$ \\
\hline the job requires more skill & $14,8 \%$ & $14,8 \%$ & $14,8 \%$ \\
\hline requirements are slightly below my qualification & $16,4 \%$ & $15,7 \%$ & $16,1 \%$ \\
\hline the requirements are much lower than my qualifications & $0,8 \%$ & $3,7 \%$ & $2,2 \%$ \\
\hline the job doesn't meet my qualifications. & $7,4 \%$ & $8,3 \%$ & $7,8 \%$ \\
\hline total & $100,0 \%$ & $100,0 \%$ & $100,0 \%$ \\
\hline
\end{tabular}

The majority of young people surveyed $(76.7 \%)$ believe that their profession is not prestigious enough. Especially on this insist girls (80.2\%). Perhaps this is the reason for the relatively low level of complete satisfaction of young people with their specialty $(27.2 \%)$, although this figure is slightly 
higher among girls (29.9\%) than among boys (24.2\%). Another third of young people (32.1\%) are more satisfied with their profession (Table 11). Situational it includes approximately every fourth young man, although among young men such a little more ( 27.3 percent). There are also more boys than girls among those who are not fully or partially satisfied with the profession, although the latter are a little more categorical.

Table 11: Gender differences in the level of satisfaction of young people with their specialty, \% by gender

\begin{tabular}{|l|c|c|c|}
\hline \multirow{2}{*}{ Satisfaction with your specialty } & Sex & \multirow{2}{*}{ In the sample } \\
\cline { 2 - 3 } & woman & man & \\
\hline completely satisfied & $\mathbf{2 9 , 9 \%}$ & $\mathbf{2 4 , 2} \%$ & $\mathbf{2 7 , 2} \%$ \\
\hline I am more satisfied & $\mathbf{3 2 , 1} \%$ & $\mathbf{3 2 , 0} \%$ & $\mathbf{3 2 , 1} \%$ \\
\hline not that I'm satisfied, but not that I'm not. & $\mathbf{2 5 , 5} \%$ & $\mathbf{2 7 , 3 \%}$ & $\mathbf{2 6 , 4} \%$ \\
\hline not very satisfied & $8,0 \%$ & $\mathbf{1 5 , 6 \%}$ & $\mathbf{1 1 , 7} \%$ \\
\hline not satisfied at all & $\mathbf{4 , 4} \%$ & $\mathbf{0 , 8} \%$ & $\mathbf{2 , 6 \%}$ \\
\hline total & $\mathbf{1 0 0 , 0} \%$ & $\mathbf{1 0 0 , 0} \%$ & $\mathbf{1 0 0 , 0} \%$ \\
\hline
\end{tabular}

To some extent, the majority of young people (67.7 per cent) are satisfied with their profession (Table $12)$. However, only one in four young people $(24.7 \%)$ is fully satisfied with it. Moreover, in contrast to the specialty, the profession to a greater extent completely satisfied men $(26,7 \%)$ than girls (22.8 per cent). Girls more boys tend to view their profession situational $(27,6 \%)$, or maximally negative (o.8 percent). Young men expressed their dissatisfaction with the profession more cautiously (7.5\%).

In the ranking of the qualities of good work, in the opinion of the youth (Table 13), in the first place came high wages ( $26.5 \%$ of responses) and its interesting content (17.7 percent) moreover, if the salary is more important for boys, then for girls - interesting content. In third place in importance were good conditions for career growth (9.1\%), which was also slightly more important for girls. In fourth place - a guarantee of preservation of the workplace $(8.5 \%)$ which is slightly more significant for boys $(9 \%)$.

Table 12: Gender differences in young people's attitudes to work, \% of responses by sex

\begin{tabular}{|c|c|c|c|}
\hline \multirow{2}{*}{ Important in work } & \multicolumn{2}{|c|}{ Sex } & \multirow{2}{*}{ In the sample } \\
\hline & woman & man & \\
\hline high wages & $\mathbf{2 5 , 2} \%$ & $28,0 \%$ & $26, \%$ \\
\hline interesting work & $\mathbf{2 1 , 1} \%$ & $13,8 \%$ & $17,7 \%$ \\
\hline guarantee of work place preservation & $8,0 \%$ & $9,0 \%$ & $8,5 \%$ \\
\hline result of work & $5,0 \%$ & $7,1 \%$ & $6,0 \%$ \\
\hline good relations with colleagues & $7,1 \%$ & $\mathbf{9 , 0} \%$ & $8,0 \%$ \\
\hline good conditions for career growth & $\mathbf{9 , 2} \%$ & $9,0 \%$ & $9,1 \%$ \\
\hline opportunities for personal and professional growth & $7,1 \%$ & $5,1 \%$ & $6,1 \%$ \\
\hline comfortable working conditions, provision of necessary means & $5,3 \%$ & $6,4 \%$ & $5,9 \%$ \\
\hline the achievement of wealth & $4,7 \%$ & $4,2 \%$ & $4,5 \%$ \\
\hline fair attitude of the Manager to the staff & $3,9 \%$ & $3,5 \%$ & $3,7 \%$ \\
\hline ease and profitability of work & $3,3 \%$ & $4,8 \%$ & $4,0 \%$ \\
\hline Total & $100,0 \%$ & $100,0 \%$ & $100,0 \%$ \\
\hline
\end{tabular}

Thus, girls are more focused on interesting content, good conditions for career growth, and opportunities for personal and professional growth, achievement of material benefits, and fair attitude of the head to the staff.

Young men are more focused on high wages, job security, and work results, good relations with colleagues, comfortable working conditions, and provision of the necessary funds, ease and profitability. 
In reality, the salary of about a third of young people is 10001-1500o rubles (Table 13), $23 \%$ receive more than 25001 rubles. One in five receives $15001-20000$ rubles. $14 \%$ receive less than 10 ,000 rubles per month. Therefore, it is not surprising that $30 \%$ of young people, especially young men (33\%) are constantly moonlighting and only $6 \%$ in the specialty, in $5 \%$ of part-time workers - work close to the specialty. Every fifth part-time job has nothing to do with his specialty.

Table 13: Gender differences in the wage, \% by gender

\begin{tabular}{|c|c|c|c|}
\hline \multirow{2}{*}{ Your salaries } & \multicolumn{2}{|c|}{ Sex } & \multirow{2}{*}{ In the sample } \\
\hline & Woman & man & \\
\hline 5000-1000o rubles & $20 \%$ & $9 \%$ & $14 \%$ \\
\hline 10001-1500o rubles & $41 \%$ & $20 \%$ & $31 \%$ \\
\hline 15001-2000o rubles & $16 \%$ & $25 \%$ & $20 \%$ \\
\hline 20001-2500o rubles & $9 \%$ & $17 \%$ & $13 \%$ \\
\hline above 25001 rubles & $4 \%$ & $18 \%$ & $10 \%$ \\
\hline I have no wages & $10 \%$ & $11 \%$ & $11 \%$ \\
\hline Difficult to answer & o & $1 \%$ & $\mathrm{o} \%$ \\
\hline Total & $100 \%$ & $100 \%$ & $100 \%$ \\
\hline
\end{tabular}

In reality, 28.7 per cent of young people are mostly satisfied with their level of wages (Table 14) and only 6.7 per cent are fully satisfied. $26,9 \%$ evaluate their satisfaction with this option work situation. $37.7 \%$ are not fully or partially satisfied with their salary. Girls are more likely to assess their salary satisfaction as positively as possible, situational or as negatively as possible. Among young men, cautiously positive or cautiously negative assessments of their satisfaction with wages are more common. Thus, the community is quite low estimates of qualified labor specialists, which causes a negative background evaluation every second representative of youth in their vocational choices.

Table 14: Gender differences in the level of satisfaction of young people with their wages, $\%$ by sex

\begin{tabular}{|l|c|c|c|}
\hline \multirow{2}{*}{ are you satisfied with your salary } & \multicolumn{2}{|c|}{ Sex } & \multirow{2}{*}{ In the sample } \\
\cline { 2 - 3 } & woman & man & \\
\hline completely satisfied & $\mathbf{7 , 1} \%$ & $6,3 \%$ & $6,7 \%$ \\
\hline I am more satisfied & $\mathbf{2 5 , 7} \%$ & $\mathbf{3 2 , 0} \%$ & $\mathbf{2 8 , 7} \%$ \\
\hline not that I'm satisfied, but not that I'm not. & $\mathbf{3 0 , 0} \%$ & $\mathbf{2 3 , 4} \%$ & $\mathbf{2 6 , 9} \%$ \\
\hline not very satisfied & $\mathbf{2 2 , 9} \%$ & $\mathbf{2 4 , 2} \%$ & $\mathbf{2 3 , 5} \%$ \\
\hline not satisfied at all & $\mathbf{1 4 , 3} \%$ & $\mathbf{1 4 , 1} \%$ & $\mathbf{1 4 , 2} \%$ \\
\hline total & $\mathbf{1 0 0 , 0} \%$ & $\mathbf{1 0 0 , 0} \%$ & $\mathbf{1 0 0 , 0} \%$ \\
\hline
\end{tabular}

The study suggested that young people should reflect on the causes of youth unemployment (Table 15). The most common opinion ( $29 \%$ of the answers) was the lack of desire of employers to employ young professionals, in second place (20.9\%) -excessive claims of young people to the desired place of work.

Table 15: Gender differences of opinion on the causes of youth unemployment, \% by sex

\begin{tabular}{|l|c|c|c|}
\hline Causes of youth unemployment & \multicolumn{2}{|c|}{ sex } & \multirow{2}{*}{ In the sample } \\
\cline { 2 - 3 } & woman & man & \\
\hline "gaps" in vocational education provided by local universities & $7,6 \%$ & $\mathbf{9 , 5} \%$ & $8,5 \%$ \\
\hline excessive claims of young people to the desired place of work & $18,0 \%$ & $\mathbf{2 4 , 1} \%$ & $\mathbf{2 0 , 9} \%$ \\
\hline lack of employers ' desire to employ young professionals & $\mathbf{3 0 , 8} \%$ & $\mathbf{2 7 , 2} \%$ & $\mathbf{2 9 , 1 \%}$ \\
\hline the lack of attention of the local administration to youth employment & $\mathbf{2 0 , 9} \%$ & $\mathbf{1 1 , 4} \%$ & $16,4 \%$ \\
\hline the passivity of the existing employment agencies & $\mathbf{6 , 4} \%$ & $5,7 \%$ & $6,0 \%$ \\
\hline
\end{tabular}




\begin{tabular}{|l|c|c|c|}
\hline \multirow{2}{*}{ Causes of youth unemployment } & \multicolumn{2}{|c|}{ sex } & \multirow{2}{*}{ In the sample } \\
\cline { 2 - 3 } & woman & man & \\
\hline reluctance of young people to work & $14,5 \%$ & $\mathbf{1 9 , 6 \%}$ & $17,0 \%$ \\
\hline Lack of experience & $\mathbf{1 , 7} \%$ & $\mathbf{1 , 3} \%$ & $1,5 \%$ \\
\hline high requirement of the employer & $0,0 \%$ & $\mathbf{1 , 3} \%$ & $0,6 \%$ \\
\hline Total & $100 \%$ & $100 \%$ & $100,0 \%$ \\
\hline
\end{tabular}

On the third (17\%) - unwillingness of young people to work thus, young people are quite self-critical. At the same time, girls almost twice as often as boys complained about the lack of attention of the local administration to the issues of youth employment $(20.9 \%)$, more often talked about the passivity of existing employment agencies and lack of experience. In other words, girls were dominated by external environmental factors of unemployment. In contrast, young men often talked about internal, subjective factors, such as excessive demands on the work of young people, employers, the reluctance of young people to work. In addition, they mentioned "gaps" in vocational education provided by local universities more often than girls.

However, the data show a discrepancy between the level of salary satisfaction (about 50\%) and dissatisfaction with their social status (17\%). This shows that it is not only mercantile guidelines that drive young people. About a third of it takes on the social responsibility of their choice of profession, focused on the substantive aspects of the work, despite the low wages.

Thus, all three vectors of secondary choice and consolidation of the chosen profession professional, personal, socio-economic - develop inconsistently. The study allows us to state that the majority of young professionals (59.1\%) primary choice of profession was successful and implemented in the specialty or close to it. Particularly consistent in these girls who differ slightly higher level of competence, but experience (more often than boys) lack of practical experience. However, there are more unemployed girls $(18 \%)$ than boys $(16 \%)$.

The occupational and gender division of labor is traditional among young people. The main areas of employment for girls are education, medicine, culture and the financial sector. Among young men dominates the service sector, then - construction, law enforcement. Industry was out of the field of employment of young professionals, although almost every fourth has a technical education. This indicates either the impossibility of employment in the specialty due to the low workload of industrial enterprises with orders, or that these young people studied at the University for the sake of a diploma, but not for the sake of the specialty. In other words, the choice of University for them did not mean the choice of work in the future. This already shows the existing background of dissatisfaction of young people with their own professional sphere.

Professional choice and its implementation in terms of practical employment is socially conditioned. It largely depends on the availability of social networking links and opportunities, as well as on the demand for the profession in the labor market. The most common way of employment is social relations, Dating (33\%). The effectiveness of employment institutions - job fairs, employment services - is still low (13\%). The efficiency of direct contacts with employers is slightly higher (16\%), but there are still many unrealized opportunities. The main obstacles to employment are the lack (especially among girls) of practical skills, experience, work experience (39\%), which demonstrates the problems of universities with the formation of young people's competencies of practical work, relations with specific employers. However, almost one in four (22\%) young professionals (especially young men $-32 \%$ ) faces a lack of demand in the labor market of their profession. It affects the consequences of the primary professional choice of young people in accordance with the preferences, but without taking into account the needs of society. No less important problem is the serious deformation in the field of remuneration of young professionals. Girls with higher levels of education have lower wages than boys. Moreover, every fifth young person, especially girls, has no opportunities for qualification growth, as the work involves lower qualifications than the specialty of young people, which generates a significant background of dissatisfaction of young people with their social and, especially - financial situation. However, the social status of about a third of young people (especially 
girls) values higher material benefits and the work focuses more on interesting content than on the value of wages, which dispels the myth of excessive pragmatism of young people.

In modern socio-economic and socio-cultural conditions of particular importance is the process of professional competence of young people, which involves the assimilation of new strategies of behavior for successful employment. Interest in the specialty is a very important factor that determines the future strategy of youth employment. The more you like the specialty, the easier graduates evaluate their future employment, the more focus on professional self-realization and career growth. This fully applies to the socio-economic strategies of the younger generation, which is just finishing higher education institutions of Russia and Kazakhstan. The survey of 2014 allowed finding out the nature of employment of University graduates of Kazakhstan (Table 13). Analysis in the framework of the gender approach showed that the resulting specialty like boys $(45,4 \%)$ than girls (39.5 per cent) . At the same time, a significant proportion of girls $46.8 \%$ chose the option "like", which shows interest in their specialty.

However, among graduates who are undecided in relation to their specialty, boys $(14.4 \%)$ more than girls (13.7\%). Perhaps this is due to the fact that when entering this part of the applicants were not professionally oriented. Among those who do not like the chosen specialty, 3.1\% were young men. Thus, female graduates are more stable in their professional orientations than boys.

Data from the 2014 study showed (Table 17 ) that $72.4 \%$ of graduates, especially girls (79.4\%) intend to work in the specialty. However, young men are slightly less focused on such work $-63.7 \%$.

Table 17: Influence of gender on the desire of graduates to work in the specialty after graduation, 2014, \% by gender

\begin{tabular}{|c|c|c|c|}
\hline \multirow{2}{*}{$\begin{array}{l}\text { Influence of gender on the desire of graduates to work in the specialty after } \\
\text { graduation }\end{array}$} & \multicolumn{2}{|c|}{ sex } & \multirow{2}{*}{ In the sample } \\
\hline & man & Woman & \\
\hline Yes & $63,7 \%$ & $79,4 \%$ & $72,4 \%$ \\
\hline No & $29,4 \%$ & $15,1 \%$ & $21,5 \%$ \\
\hline Not to think & $6,9 \%$ & $5,6 \%$ & $6,1 \%$ \\
\hline Subtotal & $100,0 \%$ & $100,0 \%$ & $100,0 \%$ \\
\hline
\end{tabular}

$65.4 \%$ of graduates of universities of Kazakhstan intend to work in the specialty, while Russian graduates $-60.4 \%$ (Table 18 ). The share of undecided with the choice of work in the specialty among Russian graduates was $13.2 \%$ of respondents, respectively among Kazakh graduates $-5 \cdot 7 \%$. This once again proves a higher level of career orientation of socio-economic strategies of Kazakhstan graduates.

Table 18: Graduates ' Desire to work in the specialty, 2015. \% of respondents

\begin{tabular}{|l|c|c|}
\hline Desire to work in the specialty & Graduates of Russian universities & Graduates of Kazakhstan universities \\
\hline Yes & $60,4 \%$ & $\mathbf{6 5 , 4} \%$ \\
\hline No & $\mathbf{2 6 , 4} \%$ & $\mathbf{2 8 , 9 \%}$ \\
\hline Never thought about it & $\mathbf{1 3 , 2} \%$ & $5,7 \%$ \\
\hline Subtotal & $\mathbf{1 0 0 , 0} \%$ & $\mathbf{1 0 0 , 0} \%$ \\
\hline
\end{tabular}

When identifying barriers in the intention to work in the specialty (Table 19), it was found that for young men the prevailing demotivates are the lack of practical knowledge, lack of work experience (33.3\%), as well as the fact that work in the specialty is low-paid (26.7\%). The reasons for girls ' reluctance to work in the specialty are somewhat different: inability to get a job in the specialty $(36.4 \%)$ and lack of interest in their specialty $(27.3 \%)$. It is likely that girls are more likely to experience difficulties in finding employment. 
Table 19: Influence of gender on the reasons of unwillingness to work in the specialty, 2014, $\%$ by gender

\begin{tabular}{|l|c|c|c|c|c|c|}
\hline Sex & $\begin{array}{c}\text { Can't get } \\
\text { settled }\end{array}$ & $\begin{array}{c}\text { Lack of practical } \\
\text { knowledge, no work } \\
\text { experience }\end{array}$ & $\begin{array}{c}\text { There is no need for } \\
\text { specialists of my } \\
\text { profile today }\end{array}$ & $\begin{array}{c}\text { Work in the } \\
\text { specialty is low- } \\
\text { paid }\end{array}$ & $\begin{array}{c}\text { I don't like } \\
\text { my specialty }\end{array}$ & Total \\
\hline Men & $\mathbf{1 3 , 3} \%$ & $\mathbf{3 3 , 3} \%$ & $3,3 \%$ & $\mathbf{2 6 , 7} \%$ & $\mathbf{2 3 , 3} \%$ & $\mathbf{1 0 0 , 0} \%$ \\
\hline Woman & $\mathbf{3 6 , 4} \%$ & $\mathbf{2 2 , 7} \%$ & $\mathbf{9 , 1} \%$ & $4,5 \%$ & $\mathbf{2 7 , 3} \%$ & $\mathbf{1 0 0 , 0} \%$ \\
\hline In the sample & $\mathbf{2 3 , 1} \%$ & $\mathbf{2 8 , 8} \%$ & $\mathbf{5 , 8} \%$ & $\mathbf{1 7 , 3} \%$ & $\mathbf{2 5 , 0} \%$ & $\mathbf{1 0 0 , 0} \%$ \\
\hline
\end{tabular}

Thus, most graduates would like to work in the specialty. Gender specificity is manifested in the fact that girls are more likely than boys to work in the specialty, but also more often say that their specialty they do not like and are not in demand in the labor market. For young men, the most demotivated of work in the specialty is the lack of experience and low wages.

\section{Discussion}

The comparative analysis of value orientations and labor practices at the initial stage of professional activity of young specialists in Kazakhstan and Russia allows us to see the common aspects of the employment process in the transforming, post-socialist States.

Analysis of scientific publications reveals that in the study of social status and behavior of University graduates the concept of "graduate" is often considered as an object of economic relations, the result of educational programs. However, insufficient attention is paid to its internal targets and peculiarities of its behavior. We need sociological research that will fill the category of "graduate" meaningfully, to reveal its main socio-cultural characteristics. The study of research on the topic of employment of graduates allows us to identify three main approaches to the interpretation of "graduate" as the object of study. It is considered as a competitive product in the labor market, as a carrier of professional and qualification potential and professional competencies, as well as an individual who has received educational services and is ready for further economic activity. In these studies, the graduate is interpreted as an object of demand in the labor market, as well as a product of professional training in universities.

University graduates as a group are distinguished by high social mobility, economic activity, increased adaptability, a tendency to innovation, a high need for self-realization, professional and life self-determination, choice of life path. They are engaged in the determination of their professional interests and status requests, the search for value and professional orientation, preparation for employment and active job search, the definition of benchmarks in a professional career.

The study showed that when hiring most employers pay attention to the availability of education, University, specialty. This was indicated by $47 \%$ of respondents (Table 8 ): $48 \%$ of girls and $44 \%$ of boys. The next important requirement of the employer is work experience, as indicated by $39 \%$ of girls and $40 \%$ of boys. The professional competence of the young specialist was more demanded by employers from boys (36\%) than from girls (21\%). Appearance and sociability employers evaluated more often in boys (4\%) than in girls. Thus, when hiring an employer, education, work experience and competence of a young specialist are especially important. Also, a study by Kirschenman and Neckerman (1991) found that appearance, communication skills and personality are vital for employers.

According to the authors, the strategies of young people and their professional choice are linked by mutual causal dependence. Strategies include a set of interiorized and developed in the course of socialization ideas about life goals and ways to achieve them. This set largely determines the professional choice of the young man. However, this choice itself, its risks and concerns, fears of possible mistakes or a bad start, can provoke a change in the vector of socio-economic strategies in the professional sense in the spirit of a new form of rationality - pragmatism. 
This pragmatism stems from the fact that the economic activities of young people are predetermined by their needs and opportunities to meet them, as well as characteristics such as health, spirituality, creativity, level of education and professionalism. Foreign researchers such as D. Belman and J. S. Heywood (1991) confirmed the impact of education on professional success and wages by using the "sheepskin" effect (sheepskin effects), i.e. it has a positive effect on earnings.

It was found that the careers of many young people were ruined because of wrong choices. In Western countries, students develop from the very beginning of their lives according to the tastes and natural skills they have. The value orientations of adolescents and parents are changing. They rationally approach the choice of profession.

Market laws focused on tough competition and selection significantly affect the motivational structure of today's youth.

\section{Conclusion}

Material and financial preferences prevail when choosing a future profession. According to the results of the study attitude to the profession of graduates and young professionals is formed under the influence of market relations and have a more rational content. Attitude to the profession is based on the demand, prestige, and profitability of the profession.

As a result of the analysis of the data of the conducted sociological research, a list of indicators and indicators was formed that comprehensively reflects the process of choosing a profession for modern youth.

Comparison of the results of the respondents ' answers shows that the desire for material values prevails in men, and women for social values. For women, the content of work is of great importance, to do what they love. Thus, all three vectors of secondary choice and consolidation of the chosen profession - professional, personal, socio-economic - develop inconsistently. The study allows us to state that the majority of young professionals (59.1\%) primary choice of profession was successful and implemented in the specialty or close to it. Particularly consistent in this girl who differs slightly higher level of competence, but experience (more often than boys) lack of practical experience. However, there are more unemployed girls (18\%) than boys (16\%).

So, if we compare the hierarchy of preferences when choosing a profession of modern Kazakh youth in the gender aspect, there is a desire and closeness of women to "Autonomous values (selfdevelopment)", and men are more inherent in all "material values". Given the small difference between the responses of men and women, it is impossible to draw unambiguous conclusions in the gender context of the value orientations of modern youth (Montayev, 2015).

It is revealed that men prefer material values more. It should be noted the importance of wealth for women. In a market environment for women seeking economic freedom is growing. Consequently, women's competitiveness in employment is also increasing. Thus, our hypothesis 3 is confirmed.

The occupational and gender division of labor is traditional among young people. The main areas of employment for girls are education, medicine, culture and the financial sector. Among young men dominates the service sector, then - construction, law enforcement. Industry was out of the field of employment of young professionals, although almost every fourth has a technical education. This indicates either the impossibility of employment in the specialty due to the low workload of industrial enterprises with orders, or that these young people studied at the University for the sake of a diploma, but not for the sake of the specialty. In other words, the choice of University for them did not mean the choice of work in the future. This already shows the existing background of dissatisfaction of young people with their own professional sphere.

Professional choice and its implementation in terms of practical employment is socially conditioned. It largely depends on the availability of social networking links and opportunities, as well as on the demand for the profession in the labor market. The most common way of employment are social relations, Dating. This is evidenced by the results of our study and thus our 4 hypothesis is 
confirmed.

The effectiveness of employment institutions - job fairs, employment services - is still low. The effectiveness of direct contacts with employers is slightly higher, but there are still many unrealized opportunities. The main obstacles in employment are the lack (especially among girls) of practical skills, experience, work experience, which demonstrates the problems of universities with the formation of young people's competencies of practical work, relations with specific employers. However, almost one in four young professionals (especially young men) is faced with the lack of demand in the labor market of their profession. It affects the consequences of the primary professional choice of young people in accordance with the preferences, but without taking into account the needs of society. No less important problem is the serious deformation in the field of remuneration of young professionals. Girls with higher levels of education have lower wages than boys. Moreover, every fifth young person, especially girls, has no opportunities for qualification growth, as the work involves lower qualifications than the specialty of young people, which generates a significant background of dissatisfaction of young people with their social and, especially - financial situation. However, the social status of about a third of young people (especially girls) values higher material benefits and the work focuses more on interesting content than on the value of wages, which dispels the myth of excessive pragmatism of young people.

According to the authors, the strategies of young people in choosing a profession and further employment are interrelated. Strategies include a set of interiorized and developed in the course of socialization ideas about life goals and ways to achieve them. This set largely determines the professional choice of the young man. However, this choice itself, its risks and concerns, fears of possible mistakes or a bad start, can provoke a change in the vector of socio-economic strategies in the professional sense in the spirit of a new form of rationality - pragmatism.

\section{References}

Belman, D., \& Heywood, J. S. (1991). Sheepskin effects in the returns to education: An examination of women and minorities. The Review of Economics and Statistics, 73(4), 720-724.

Bennett, N., Dunne, E., \& Carre, C. (1999). Patterns of core and generic skill provision in higher education. Higher Education, 37, 71-93.

Boswell, W. R., Boudreau, J. W., \& Dunford, B. B. (2004). The outcomes and correlates of job search objectives: Searching to leave or searching for leverage? Journal of Applied Psychology, 89, 1083-1091.

Feld, S. L. (1981). The focused organization of social ties. The American Journal of Sociology, 86(5), 1015-1035.

Finko, M. V. (2006). The competitiveness of the modern university and the employment of graduates. In: A. G. Sapronov (Ed.), Experience and problems of employment of graduates of universities in the Southern Federal District: Materials I Intercollege Scientific-practical Conference (pp. 144-153). Shakhty: Izd-vo SRSUES.

Hillage, J., \& Pollard, E. (1998). Employability: developing a framework for policy analysis. Research Brief No. 85. Department for Education and Employment, London. Available: www.dfes.gov.uk/research/data/uploadfiles /RB85.doc (date of access: February 2, 2007).

Holland, J. H., Holyoak, K. J., Nisbett, R. E., \& Thagard, P. (1986). Induction: Processes of inference, learning, and discovery. Cambridge, MA: MIT Press.

Johnes, G. (2006). Career interruptions and labour market outcomes. EOC Working Paper Series No. 45. Equal Opportunities Commission, Manchester.

Kanfer, R., Wanberg, C. R., \& Kantrowitz, T. M. (2001). Job search and employment: A personality-motivational analysis and meta-analytic review. Journal of Applied Psychology, 86, 837-855.

Kirschenman, J., \& Neckerman, K. M. (1991). Hiring strategies, racial bias, and inner city workers. Social Problems, $38(4), 433-447$.

Montayev, A. B. (2015). Job search strategies of university graduates of Russia and Kazakhstan: a cross - cultural approach. Proceedings of Higher Educational Institutions. Povolzhsk Region. Social Sciences, 1(33), 125-132.

Safina, R. G. (2005). Students' choice of professional career: Gender aspects (on the example of the Republic of Tatarstan): Dis. ...Cand. sociol. Sciences: 22.00.04. Kazan State University, Kazan, Russia, 193 p.

Shnarbekova, M. (2018). The motivations behind educational and professional choices of Kazakhstani youth (based on the results of sociological studies). Russian Education $\mathcal{E}$ Society, 6o(4), 370-380. 
Sizova, L., Kladova, N. V., \& Khusiainov, T. M. (2016). Postgraduate strategies of classical university graduates: the gender aspect. Woman in Russian Society, 1(78), 6o-68.

Srijit. (2009, February). The choice of profession. India Study Channel. Available: www.indiastudychannel.com/resources/4986o-Choice-profession.aspx

Super, D. E., Crites, J., Hummel, R., Moser, H., Overstreet, Ph., \& Warnath, CH. (1957). Vocational development: A framework of research. New York, NY: Bureau of Publications, Teachers College, Columbia University. 